OECD Science, Technology and Industry Working Papers 2002/11

\title{
Competition Policy and Innovation
}

\section{Carl Shapiro}


Organisation de Coopération et de Développement Economiques

DIRECTORATE FOR SCIENCE, TECHNOLOGY AND INDUSTRY

STI WORKING PAPERS 2002/11

COMPETITION POLICY AND INNOVATION

Professor Carl Shapiro

Haas School of Business, University of California at Berkeley 


\section{STI Working Paper Series}

The Working Paper series of the OECD Directorate for Science, Technology and Industry is designed to make available to a wider readership selected studies prepared by staff in the Directorate or by outside consultants working on OECD projects. The papers included in the series cover a broad range of issues, of both a technical and policy-analytical nature, in the areas of work of the DSTI. The Working Papers are generally available only in their original language - English or French - with a summary in the other.

Comment on the papers is invited, and should be sent to the Directorate for Science, Technology and Industry, OECD, 2 rue André Pascal, 75775 Paris Cedex 16, France.

The opinions expressed in these papers are the sole responsibility of the author(s) and do not necessarily reflect those of the OECD or of the governments of its Member countries.

http://www.oecd.org/sti/working-papers 
DSTI/DOC(2002)11

\author{
COMPETITION POLICY AND INNOVATION \\ Professor Carl Shapiro \\ Haas School of Business \\ University of California at Berkeley
}

This paper seeks to improve understanding of the links between innovation and competition policy. It is intended to help OECD Member countries identify ways in which they can design and implement policies that best promote innovation while protecting against anti-competitive behaviour. Special attention is given to the need for firms to co-operate during the innovation process, e.g. by forming joint ventures and by engaging in co-operative standard setting activities, and the special challenges such co-operation poses for competition policy. The paper specifically addresses competition challenges that arise from inter-firm co-operation that aims to commercialise inventions, diffuse innovation more broadly throughout the economy, or extend and elaborate on existing technology. Although the economic principles articulated here apply across the entire economy, the paper focuses attention on the information and communications technology sector, where the opportunities for innovation are considerable, where collaboration has proven to be a central element of industry performance, and where a number of prominent competition policy cases have arisen. It relies extensively on US antitrust law and case law, but the underlying economic principles are the same around the world. 


\title{
POLITIQUE DE LA CONCURRENCE ET INNOVATION
}

\author{
Professeur Carl Shapiro
}

\author{
Haas School of Business \\ University of California at Berkeley
}

\begin{abstract}
Ce papier a pour objectif de contribuer à une meilleure compréhension des relations entre innovation et politique de la concurrence afin d'aider les pays-Membres de l'OCDE à identifier des orientations pour la conception et la mise en œuvre de politiques de soutien à l'innovation tout en restreignant les pratiques anti-concurrentielles. Une attention spéciale est portée sur les besoins de coopération entre firmes au cours du processus d'innovation, à travers notamment la formation de joint ventures ou la détermination de standards communs, ainsi que sur les enjeux posés à la politique concurrentielle par la coopération technologique. Dans cette perspective, ce papier discute spécifiquement des enjeux liés à la concurrence que soulèvent les coopérations inter-firmes ayant pour objectifs la commercialisation des inventions, l'accroissement de la diffusion des innovations dans l'économie, ou encore l'élaboration à partir de technologies existantes. Bien que les principes économiques décrits s'appliquent à l'ensemble des activités économiques soumises à concurrence, ce papier porte plus particulièrement sur le secteur des technologies de l'information et des communications au sein duquel les opportunités d'innovation sont considérables, les collaborations ont montré leur rôle crucial pour la performance industrielle, et où un nombre conséquent de problèmes liés à la politique de la concurrence ont été soulevés. Il se base essentiellement sur la législation anti-concurrentielle et des cas de jurisprudence aux Etats-Unis mais les principes économiques sous-jacents demeurent les mêmes ailleurs.
\end{abstract}


TABLE OF CONTENTS

COMPETITION POLICY AND INNOVATION .3

COMPETITION POLICY IN PERSPECTIVE 6

THE ROLE OF COMPETITION POLICY IN THE INNOVATION PROCESS ...................................... 8

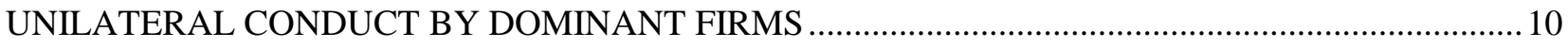

MERGERS AND ACQUISITIONS IN HIGH-TECH INDUSTRIES ..................................................... 19

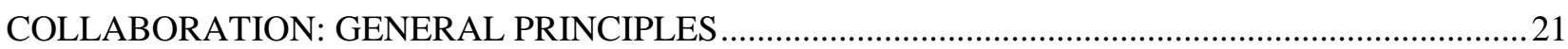

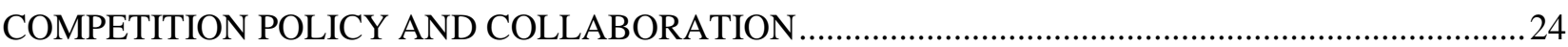

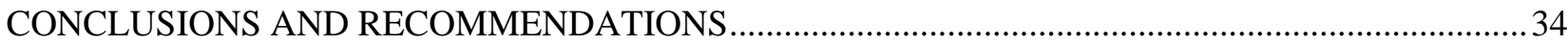




\section{COMPETITION POLICY IN PERSPECTIVE}

While competitive markets are no doubt important in fostering innovation, there should be no illusion that the marginal changes that Member countries might reasonably make to their competition policies in the foreseeable future are likely to be major drivers of economic growth or the rate of innovation, either by country or worldwide. Generally speaking, competition regimes are conducive to innovation and act gradually over time as companies learn new rules regarding licensing and collaboration, so dramatic effects in the short- or medium-term resulting from changes in competition policies are unlikely. Surely such policies as training of scientific and technical personnel, funding for basic research, the tax treatment of R\&D expenditures, support for financial institutions that fund risky R\&D activities, and the scope of intellectual property rights (IPRs) are more important drivers of innovation.

The OECD has in fact identified these and other policies (such as new types of financing and the reform of science-industry relationships) that support growth based on innovation, especially regarding information and communications technology (ICT). ${ }^{1}$ There is a substantial body of literature addressing the overall conditions that are conducive to innovation, ${ }^{2}$ as well as a number of studies assessing how commercial firms appropriate the returns from their R\&D activities. ${ }^{3}$ This paper takes all of these considerations as background for the current discussion of competition policy.

Understood in context, sound competition policy can complement the primary policy instruments noted above. Competition policy based on economic reasoning — rather than legal formalisms - does not fundamentally conflict with pro-growth and pro-innovation policies in these other areas. This is even true where intellectual property rights and antitrust appear to be at odds. Much of this paper is devoted to the perceived tension between intellectual property rights and competition policy - "perceived" because there is not necessarily an inherent or inevitable conflict between these two areas of law and policy. ${ }^{4}$

1 See "Policies That Support Growth Based on Innovation and Information Technology," Chapter 4, in $A$ New Economy? The Changing Role of Innovation and Information Technology in Growth, OECD, 2000.

2 For one recent window into this literature, see Scott Stern, Michael Porter, and Jeffrey Furman, "The Determinants of National Innovation Capacity", NBER Working Paper \#7876, September 2000, available at www.nber.org/papers/w7876, which looks at the factors driving patenting by country. This study suggests that the following factors determine "national innovative capacity": R\&D manpower and spending, extent of patent protection, openness to international trade, and funding of academic research by the private sector. Stern, et al find that there has been a convergence over the past 25 years among OECD countries in terms of their innovative capacity. See also Richard Nelson, ed., National Innovation Systems: A Comparative Analysis, Oxford University Press, 1993.

3 A recent contribution is Cohen, Wesley M., Richard R. Nelson and John Walsh, (2000) "Protecting Their Intellectual Assets: Appropriability Conditions and Why U.S. Manufacturing Firms Patent (Or Not)," National Bureau of Economic Research, Working Paper \#7552, February, available at http://papers.nber.org/papers/w7552. See, more generally, the NBER project on Industrial Technology and Productivity, at http://www.nber.org/sloan.

Quite a few authors have previously addressed the interaction between Competition Policy and Intellectual Property Rights. See especially the OECD Roundtable on Competition Policy and Intellectual Property Rights, on which this paper is intended to build: http://www.oecd.org/daf/clp/Roundtables/IPR00.htm. 
Despite the importance of competition policy, arising from the fact that competition policy affects the very fabric of competition and business behaviour, this paper makes no empirical assertions regarding the relationship between specific antitrust policies (or other regulatory policies, for that matter) and rates of growth by country. Competition promotes innovation, in high-tech industries as in other industries, and the impressive performance of the US economy over the past decade reflects that linkage, but the paper does not make any effort to "prove" that link. 


\section{THE ROLE OF COMPETITION POLICY IN THE INNOVATION PROCESS}

Where does competition policy enter into the innovation process? Competition policy plays a relatively modest role in basic research. After all, a great deal of basic research does not take place at for-profit companies. And basic research that is conducted in the private sector, especially research conducted unilaterally by a single entity, is generally not constrained by competition policy. To the extent that competition policy limits pure research activities, such constraints arise through limits on the ability of two or more companies to conduct joint research. As discussed below, competition authorities around the world have gone out of their way to communicate that they will not stand in the way of research joint ventures (RJVs) and other forms of collaboration at the research stage. In the United States, for example, legislation was passed expressly to ease antitrust limits on RJVs and limit private damage claims to single ( vs. treble) damages when registered research joint ventures are involved. There are virtually no examples of joint research activities that have been blocked on antitrust grounds. All in all, the notion that basic research has elements of a public good, and thus is well suited for RJVs and industry consortia, is well accepted in antitrust circles. In particular, collaboration is accepted as the most appropriate way to conduct a range of so-called "pre-competitive" research, i.e. research that can effectively be used and shared by a number of industry participants, serving as a common base from which firms can later compete by developing their own specific products.

Nor does competition policy directly play a very active or visible role in the process of invention. ${ }^{5}$ In the United States, the Federal Trade Commission (FTC)/Department of Justice (DOJ) Guidelines for the Licensing of Intellectual Property ("IP Guidelines") talk about "innovation markets", but this mode of analysis can quite easily be seen as involving traditional issues of potential competition. Two examples should illustrate this point. First, the FTC has required divestitures in several merger cases where the merging parties were each developing pharmaceuticals in the same therapeutic category. These can best be seen as traditional horizontal merger cases in which the actual market competition was several years away, after the completion of clinical trials and after FDA approval of the drugs in question. Second, the DOJ or the FTC has found problems with various defence mergers where the merging parties were seen to have the most advanced capabilities in the development of certain military equipment or weapons. Again, these cases can easily be seen as potential competition cases: in five years, when the next major procurement in a given area will likely take place, the US Department of Defense expects that the two merging parties will offer important choices that will make procurement more competitive. In these cases, and others, mergers have been blocked or modified based on the "capabilities" of the merging parties, or based on their overlap in an "innovation market." Properly applied, this doctrine can spur innovation by making sure that independent research approaches are pursued and multiple paths to invention are kept open.

The impact of competition policy on innovation is more pronounced in efforts to commercialise new science and technology, to diffuse innovations more broadly throughout the economy (whether or not

$5 \quad$ Competition Policy can greatly influence the incentives for private firms to incur the costs necessary to produce inventions, but these impacts arise through rules limiting subsequent behaviour and returns during the commercialisation, diffusion and extensions phases of the innovation process. For example, mandatory licensing, discussed below, can reduce the returns to invention. 
they are based on new science and technology), and to extend, or build upon, existing inventions. It is during these processes that licensing, cross-licensing, patent pools, joint ventures, alliances, and mergers all come into play. These are processes in which intellectual property rights are asserted and can dramatically affect both the return to R\&D and the actual pattern of adoption of new technologies.

In the past several years, the United States, Canada, and Japan have all issued guidelines regarding licensing and intellectual property rights more generally. In the United States the "Guidelines for the Licensing of Intellectual Property" were issued by the DOJ and the FTC in April 1995. ${ }^{6}$ In Canada, the "Intellectual Property Enforcement Guidelines" were issued in $2000 .^{7}$ In Japan, the "Guidelines for Patent and Know-How Licensing Agreements" were issued in July 1999. ${ }^{8}$ Similarly, in 1996 the EU published Regulation No 240/96 concerning Technology Transfer Agreements. ${ }^{9}$ These guidelines were a natural response to the rapidly growing significance of intellectual property as a source of competitive advantage, as a driver of competitive strategies, and as a key determinant of the conditions of entry into many markets. These various guidelines have served a very useful role in communicating to the business community the principles employed by competition officials in assessing a variety of business arrangements involving intellectual property.

To track the role and impact of competition policy in these areas, this paper will now look at several of the major categories of commercial conduct that are constrained by competition policy. ${ }^{10}$ First, it looks briefly at unilateral conduct by dominant firms, including refusals to license and the imposition of various restrictions in licenses. Next, it turns to mergers in industries experiencing rapid technological change. Third and most extensively, it considers various forms of collaboration, including joint ventures, standard setting, cross-licenses, and patent pools.

$6 \quad$ See http://www.usdoj.gov/atr/public/guidelines/ipguide.htm.

$7 \quad$ See http://strategis.ic.gc.ca/SSG/ct01992e.html.

$8 \quad$ See http://www.jftc.go.jp/e-page/guideli/patent99.htm

9 See http://europa.eu.int/eur-lex/en/lif/dat/1996/en_396R0240.html. The EU is reviewing this regulation to assess its impact and effectiveness. See http://europa.eu.int/comm/competition/antitrust/others/.

This paper does not directly address price-fixing because the connection between classical price fixing and innovation is relatively indirect: competition on price for market share does stimulate firms to lower cost and improve quality, which fuels innovation, but this is just the general link between competition and innovation, nothing more direct or specific. 


\section{UNILATERAL CONDUCT BY DOMINANT FIRMS}

\section{Refusals to license}

Although this paper is focused on collaboration, the legal treatment of unilateral conduct, in particular refusals to license intellectual property, is also important, both as it affects the ability of firms to appropriate returns to $\mathrm{R} \& \mathrm{D}$, and as it determines the "threat points" that apply in negotiations between, e.g. patent holders and would-be licensees. Put differently, in order to understand how firms negotiate various collaborative arrangements - from straight patent licenses to joint ventures and patent pools one must first understand how competition will proceed, and how profits will be earned, if two or more firms fail to reach an agreement to collaborate.

Intellectual property rights and competition policy are often thought to be at odds. This is generally incorrect: both policies have the same aim, namely to stimulate innovation and the subsequent commercialisation of technologies that ultimately benefit consumers. But there is indeed a genuine and inevitable short-term trade-off between promoting innovation and diffusion: there is a perpetual temptation in the short-run to tilt towards greater diffusion, even if this means circumscribing intellectual property rights. Competitors and/or consumers will typically welcome such shifts, whose true costs are only felt in the longer term as they come to affect incentives to conduct R\&D. ${ }^{11}$ This tension is most directly felt in the area of mandatory licensing of patents or copyrights. Since patents are explicitly intended to grant exclusive rights to new and useful inventions and thus to serve as barriers to entry, whereas copyrights have the narrower objective of protecting the expression of an idea but not the idea itself, the legal treatments of these two forms on intellectual property are distinct, and they are discussed separately below. For example, the "fair use" doctrine explicitly permits the limited use of copyrighted material without the rights holder's permission; there is no comparable doctrine regarding patents.

In the United States, courts have generally been very wary of requiring firms, even dominant firms, to deal with their competitors. There are cases involving a duty to deal, sometimes referred to as the "essential facilities doctrine," but usually the duty is only triggered by a prior course of dealing. ${ }^{12}$ One of the inevitable problems with imposing a duty to deal is that the courts tend to be drawn into the question of the terms on which the dealing must take place, i.e. the courts tend to become regulators of price and other terms and conditions of commercial relationships, which is hardly their comparative advantage. Likewise, plaintiffs seeking mandatory licenses typically argue that such licenses "will not be very costly for the patent holder" because the licensees are willing to pay a reasonable royalty. But this is a poor argument: the courts must determine what is "reasonable," and if the so-called "reasonable royalty" indeed would

$11 \quad$ Note that any ex post strengthening of intellectual property rights already granted will tend to discourage diffusion without having any direct effect on innovation. For this reason, moves such as lengthening the term of copyright protection long after the affected works were created are undesirable. Highlands Skiing Corp., 472 U.S. 585 (1985) in which the larger ski resort was required to continue to offer joint tickets with its smaller rival. 
make the patent holder whole, it should be easy for the licensee to convince the patent holder to license on a voluntary basis.

\section{Patents in the United States}

The reluctance of US Courts to impose a duty to deal has been especially strong when intellectual property rights, especially patents, are involved, making mandatory licensing extremely rare. One widely noted exception was the Kodak case in the Ninth Circuit Court of Appeals. ${ }^{13}$ In the Kodak case, Kodak refused to sell spare parts to independent service organisations seeking to service Kodak micrographics equipment and Kodak copiers. Kodak argued on appeal that it had an absolute right to refuse to sell its patented parts. The Appeals Court ruled that Kodak's assertion of patent rights was "pretextual", and upheld the jury finding that Kodak's refusal to sell these parts had been an illegal act of monopolisation of the service business for Kodak equipment. There should be no doubt that rulings along these lines erode patent rights and tend to reduce the return on conducting R\&D. ${ }^{14}$

One reason the Kodak case has been so heavily criticised is the tortured legal standard adopted by the Court: a company can refuse to license if its intention was to exert its valid patent rights, but not if its intention was to merely get a return on its R\&D investment or to exclude rivals. This standard is, in many ways, both economic nonsense and unworkable in practice. Many companies apply for patents precisely to have the right to (at least threaten to) exclude competitors (from infringing), and precisely to capture a return on the R\&D that led to the patents. The Kodak case is a good example of legal formalisms triumphing over economics and common sense.

Fortunately, the impact of the Kodak case, unique to begin with, ${ }^{15}$ is now limited by other, conflicting opinions. Most notably, last year in the Xerox case, the appeals court responsible for patents, the Federal Circuit, issued a strongly-worded opinion granting patent holders a broad right to refuse to license their patents, regardless of the competitive consequences. ${ }^{16}$ The case is especially striking as it involved basically the same practice, and even the same markets, as the Kodak case. Xerox, like Kodak, refused to sell its patented parts to independent service organisations seeking to service Xerox copiers. The Federal Circuit ruled that Xerox had an absolute right to refuse to license its patents or sell its patented parts to its rivals. The Xerox Court was very clear that "absent exceptional circumstances, a patent may confer the right to exclude competition altogether in more than one antitrust market." The Xerox Court held that the patent holder's subjective intention in refusing to license its patent is irrelevant.

13 Image Technical Services, Inc. vs. Eastman Kodak Company, 125 F. 3d 1195, 1201 (9th Cir. 1997).

An ironic aspect of the Kodak case is that Kodak was the entrant and challenger in the copier market, going against the much larger and more established Xerox. Part of Kodak's entry strategy was to offer discounts on equipment and gain a return on investment in part from profit margins on parts and service. To the extent that imposing a mandatory duty to sell patented parts disrupts this type of entry strategy, both innovation and competition are adversely impacted. The author served as an expert witness for Kodak in this case.

The Kodak court itself stated that it could find "no reported case in which a court ha[s] imposed antitrust liability for a unilateral refusal to sell or license a patent."

16 Independent Service Organisations Antitrust Litigation, US 203 F.3d 1322 (Fed.Cir. 2000). The Federal Circuit did make it clear that enforcement of invalid patent rights, or sham litigation using patents, could violate the antitrust laws. 


\section{Copyrights in the United States}

The situations under which copyright owners are required to grant licenses to their copyrighted works are also somewhat unclear. US Courts have tended to take the view that copyrights are not necessarily intended to give broad market control to their owners. Fair use doctrine, which defines conditions under which copyrighted material can be used without the necessity of obtaining permission (and, thus, paying royalties) from the holder of the copyright, also can be applied. For example, in the famous Borland v. Lotus case, Borland sought to use certain aspects of the Lotus 1-2-3 spreadsheet software program to make it easier for users to switch from Lotus 1-2-3, then the dominant spreadsheet program, to Borland's rival Quattro-Pro spreadsheet program. Ultimately, Borland's use of certain aspects of the Lotus user interface was ruled legal under a fair use doctrine.

The issue of how to treat copyrighted interfaces has come up repeatedly, and will surely arise in the future. These cases are not so much about "mandatory licensing" of intellectual property as, rather, about the proper scope of intellectual property rights. One of the most extensive discussions of a unilateral refusal to license copyrighted software was in the Data General case in the First Circuit Court of Appeals. ${ }^{17}$ In this case, Data General was accused of maintaining its monopoly in the market for the service of Data General computers by unilaterally refusing to license certain diagnostic software to Grumman and other competitors. In Data General, the court established as a legal standard that "while exclusionary conduct can include a monopolist's unilateral refusal to license a copyright, an author's desire to exclude others from use of its copyrighted work is a presumptively valid business justification for any immediate harm to consumers." The Data General court explicitly held that while the "essential facility" doctrine could not be used to mandate the licensing of patents, copyright holders were not legally immune from challenges - and thus the potential of mandatory licensing — under this doctrine.

\section{Copyrights in Europe}

Two cases indicate that owners of copyrights in Europe are more likely to be found to have acted anti-competitively by simply refusing to license their copyrights than would their US counterparts. ${ }^{18}$

The first case is the 1995 Magill case decided by the European Court of Justice. ${ }^{19}$ In Magill, a number of television stations in the United Kingdom and Ireland published their own weekly guides to their programs. When Magill attempted to publish a comprehensive weekly guide, the stations asserted copyright protection for their program information. The Court found these refusals illegal under Community law. The Court based its decision on a finding that the refusals prevented the appearance of a new product (the comprehensive weekly guide) for which there was potential consumer demand. Although the Court suggested that the facts of the Magill case were unusual and thus that the duty to license would

Data General Corp. vs. Grumman Systems Support Corp., 36 F.3d 1147 (First Circuit, 1994).

These two cases are not the only ones relevant in the EU; they merely are the most visible and most recent. More than a decade ago the Volvo case clearly established the possibility of compulsory licensing: "the exercise of an exclusive right by the proprietor of a registered design in respect of car body panels may be prohibited by Article 86 if it involves, on the part of an undertaking holding a dominant position, certain abusive conduct such as the arbitrary refusal to supply spare parts to independent repairers, the fixing of prices for spare parts at an unfair level or a decision no longer to produce spare parts for a particular model even though many cars of that model are still in circulation..." See Volvo AB v. Erik Veng (U.K.) Ltd. (238/87), [1988] E.C.R. 6211, [1989] 4 C.M.L.R. 122, C.M.R. 14498.

See the Judgment of 6 April 1995, Joined Cases C-241/ P and C-242/91 P, RTE and IPC v. Commission. This case grew out of a 1988 decision by the European Commission and a 1991 decision by the Court of First Instance. 
only arise in exceptional circumstances, the fact is that the underlying economic pattern described was not exceptional in situations where a copyright holder and a potential licensee fail to agree on licensing terms. If the "new product" does not compete with existing products, we would expect voluntary negotiations over a copyright license to bear fruit. If the "new product" does compete against the copyright holder's existing offerings, then a mandatory license would presumably reduce the return to the creative efforts that led to the copyright in the first place. A more satisfactory result would be to decline to grant copyright protection to mere listings of information, or, for example, for arbitrary interface specifications that do not reflect meaningful creative efforts.

The second case involves IMS Health, a world leader in providing data on pharmaceutical products. In March 2001 the European Commission stated its preliminary intention to require IMS Health to offer a license to its copyright on the data structure IMS Health uses for its data in Germany. ${ }^{20}$ According to the European Commission, "The statement of objections concludes that the refusal in question is a prima facie abuse of a dominant position within the meaning of Article 82 of the European Treaty." ${ }^{21}$ Since this principle is not limited to interface information, the IMS Health case again raises the prospect of a direct conflict between the principles of copyright protection (as a means of rewarding creative efforts) and competition policy as practised at the European Commission.

A more coherent approach might be to circumscribe copyrights - either by limiting the type of information subject to copyright protection or by expanding the scope of "fair use" - rather than to grant them more broadly and then impose mandatory licensing. This is one instance of a general rule that can be used for policy making: grant well defined intellectual property rights, and then let the owners of those rights exercise them (unilaterally) without fear of antitrust liability. If the balance needs to be struck more towards diffusion and less towards invention, then the intellectual property rights should be trimmed back rather than mandatory licensing imposed..$^{22}$ Among other advantages, this approach relieves the Courts of the task of determining what are "reasonable" licensing fees when such licensing is mandated.

\section{Looking ahead}

It seems likely that the boundary between copyright and competition policy will become more important in the near future, given the importance of copyright protection in the software industry and in the entertainment industry more generally (from music and movies to computer and video games). Software is surely the trickiest area, if nothing else because of the importance of software interfaces. For example, the disclosure of Application Program Interfaces (APIs) has been a central issue in the remedy phase of the Microsoft antitrust case. In the Microsoft case, APIs are the interfaces that applications use to call upon the operating system to obtain services from the operating system. By giving superior API information to its internal developers of applications, such as Microsoft Office, Microsoft has the ability to advantage its applications developers over third-party developers of applications. More generally, antitrust issues are likely to arise when software companies controlling a "platform" favour their own internal developers writing software that runs on that platform. Such favouritism can occur through the selective disclosure of interface information, which can include the quantity, quality, and timing of such disclosure.

20 See European Commission announcement regarding IMS health, 14 March 2001, available at http://europa.eu.int/rapid/start/cgi/guesten.ksh?p_action.gettxt=gt\&doc=IP/01/365|0|RAPID\&lg=EN.

On 26 October 2001, the Court of First Instance of the European Communities suspended the operation of the Commission's decision pending its judgement on the appeal against the decision. Further information about the IMS Health case can be found at: http://europa.eu.int/comm/competition/antitrust/cases/2001/ under "1.1 Published Decisions;" the IMS Health Decision is dated 7 March 2001.

As discussed below, there are many dimensions on which IPRs can be trimmed back, not only the length or breadth of patent or copyright protection. 
Similar disclosure and interface issues can arise when a dominant provider of a key piece of infrastructure software introduces new versions of its software and other companies claim that the new interfaces are less "open" than older interfaces, or are "biased" towards the original company's complementary products.

There should be no illusion that mandatory licensing "only" affects a few holders of patent or copyrights who have acted in an exclusionary manner by refusing to license their intellectual property. License negotiations take place in the shadow of possible mandatory licensing - so the impact of mandatory licensing far exceeds the actual cases where mandatory licensing is decreed. The impact extends to many other licensing situations and thus affects longer-term innovation incentives. Certainly in the United States, where antitrust liability in private cases imposes treble damages, the awareness of the Kodak case in the antitrust counselling community has been considerable. Either the case will have little impact - if companies can simply learn to justify a refusal to license based on patents rather than return to $\mathrm{R} \& \mathrm{D}$ - or the case will have an adverse impact on innovation.

\section{Licensing restrictions}

A much richer set of competition issues arises when looking at various licensing restrictions or conditional licenses. In the United States and the EU there remains some genuine uncertainty about the precise antitrust limits imposed on patent holders when they structure licenses that they choose to offer. While these issues potentially arise whenever intellectual property is involved, they take on added importance and urgency in the information technology sector for four inter-related reasons: $(i)$ rapid technological change: information technology is experiencing especially rapid technological progress, so the returns to innovation are crucial to market performance; (ii) importance of interfaces: to deliver value to customers, information technology typically requires a variety of technologies or products to work in concert, and this in turn requires significant licensing of patents, copyrights, and trade secrets, including licenses to use interfaces to interoperate; (iii) complex technologies: the increased number of patents, and the increased propensity to patent have created a "patent thicket" that often requires firms to obtain multiple licenses in order to obtain the freedom to design their products and bring them to market free of serious patent infringement claims; and (iv) hold-up and opportunism: since no disclosure is required when a patent application is filed ${ }^{23}$, companies introducing new products that incorporate state-of-the-art technology may find that they are unwittingly infringing on patents issued after their product design decisions were made and significant resources were sunk in developing the new product. ${ }^{24}$

\section{Some general principles}

The Federal Circuit stated in the Xerox case (cited above) that "In the absence of any indication of illegal tying, fraud in the Patent and Trademark Office, or sham litigation, the patent holder may enforce the statutory right to exclude others from making, using, or selling the claimed invention free from liability under the antitrust laws." Critics have faulted the Federal Circuit for confining antitrust concerns to this short list of conduct. Certainly, there are provisions in patent licenses other than tying restrictions that can harm competition and go beyond the scope of the patent grant; for example, a requirement that licensees refuse to deal with the patent holder's competitors could stifle competition. Those various restrictions are discussed below.

When a patent application is filed in the Unites States only, the applicant may ask the USPTO not to publish the application prior to granting the patent.

These issues are discussed at length in Carl Shapiro, "Navigating the Patent Thicket: Cross Licenses, Patent Pools and Standard Setting," in Innovation Policy and the Economy, Adam Jaffe, Joshua Lerner, and Scott Stern, eds., National Bureau of Economics, 2001. 
First, one must recognise the principle that conditional licenses can have effects on competition which are quite distinct, and potentially more harmful, than unconditional refusals to license. Even if one adopts the approach advocated above, namely that patent holders should have the right to keep their inventions to themselves and refuse to grant licenses, it does not follow that patent holders have free reign to issue restricted licenses, or to issue licenses only to entities meeting certain conditions. Tying is just one such restriction: the grant of a patent license conditional upon the licensee purchasing other products from the patent holder. As is widely recognised, tying can be a means by which the patent holder extends its control beyond the scope of its patent. Exclusive dealing - prohibiting the licensee from purchasing products from rivals - is another such method. Notice that a conditional license creates incentives for licensees that cannot be achieved through a simple refusal to license. In the case of exclusive dealing, the potential licensee faces a high price for dealing with rivals, namely an inability to practice the patented invention. The greater the market power enjoyed by the patent holder, and the more attractive the license is to licensees, the stronger is this potentially anti-competitive incentive effect.

Using Microsoft as an example, while Microsoft presumably has the right to refrain from licensing copyrighted Windows software (obviously, this would not be a very profitable approach), Microsoft would face an obvious antitrust challenge were it to attempt to license Windows to computer OEMs conditional on their not selling any computers with Apple or Linux or Unix software. Such conditional licenses could impede rivals far more than a flat refusal to license Microsoft Windows.

Once it is recognised that conditional licensing can pose competition problems, it is immediately clear that such an anti-competitive aim could be achieved by selectively licensing a critical patent or copyright. Sticking with the Microsoft example, think of the incentives created if Microsoft selectively licensed Windows to computer OEMs who did not offer any Linux machines (or who did not load the Netscape browser on their machines). Clearly, this policy would be very similar in its effects to a policy of conditional licensing, especially if the licenses are fairly short-lived, so that Microsoft would decline to renew the license of an OEM who started selling Linux machines. The difficulty here from an enforcement perspective is that selective licensing is harder to detect than conditional licenses: conditional licenses by definition contain explicit restrictions in the actual language of the license, while selective licensing might only be observed by inference looking over a sample of who did, or did not, receive a license. All of these enforcement difficulties are worsened when the licensees are heterogeneous and when there are legitimate reasons for licensing terms to differ across licensees.

These practical enforcement problems become all the more pronounced if there are various qualitative features of licenses that matter a great deal commercially but are hard for enforcement authorities or courts to observe. For example, suppose that the timing and completeness of disclosure about interface information from Microsoft to a licensee, within the context of a Windows license, matters a great deal to the OEM (who must compete with other OEMs) but is hard for outsiders to evaluate. Then Microsoft could, at least in principle, give interface information more quickly, and with better explanations and support, to "favoured" OEMs who are loyal to Microsoft in various ways. Again, one has what amounts to selective licensing. The general principle is that anti-competitive behaviour can take place in the context of a patent or copyright license, even if one accepts the principle that rights holders can legitimately refrain from licensing in the first place.

Much of the Microsoft antitrust case in the United States can be viewed in this way: Microsoft gains no immunity from the fact that Microsoft Windows and Internet Explorer have copyright protection and Microsoft's dealings with OEMs (and others) take place within the context of a copyright license. The European Commission has also acted to stop Microsoft from imposing anti-competitive restrictions in its licensing of Internet Explorer. In 1999, the Commission approved Microsoft's revised Internet Explorer licensing agreements with Internet Service Providers (ISPs). The Commission was concerned that Microsoft's original licenses would have excluded Microsoft's rivals in the market for Internet browser 
software. The restrictions at issue would have had the effect of raising the (opportunity) cost to ISPs of using browsers other than Internet Explorer. One provision Microsoft agreed to drop would have terminated an ISP's license if it failed to meet certain distribution volumes and percentages for Internet Explorer. Another provision restricted the ability of the ISP to promote and advertise competing browser software.

"Licensing restrictions" are included here in the section on unilateral conduct by dominant firms, but it should be clear that licensing restrictions can also be considered as ways of governing collaboration between a dominant firm and its customers, suppliers, competitors, or complementors. Effectively, by prohibiting certain restrictions, competition policy prevents the dominant firm and its customers (in this example) from becoming too closely aligned through various loyalty arrangements and exclusivity provisions. It is important to understand that these antitrust rules are not just a matter of shifting the bargaining power between the dominant firm and its customers: the customers might be delighted to agree to exclusivity (for example) in exchange for other considerations (reduced license fees, for example, or other more favourable treatment). The point of the antitrust rules is that these mutually attractive deals can exclude rivals to the dominant firm and cement that firm's dominant position, to the ultimate detriment of customers.

All of this suggests an important distinction between two types of licensing restrictions. This distinction in fact is made in the US IP Guidelines. On the one hand there are restrictions that simply limit the extent of the grant to use the licensor's intellectual property. Such restrictions will not typically prevent competition that would have taken place in the absence of the license. On the other hand there are restrictions that, either explicitly or through their inevitable workings, act to limit the licensee's ability to deal with the licensor's rivals or act in other ways to limit the ability of the licensor's rivals (which may include the licensee itself) to compete effectively. The latter category of restrictions is far more worrisome than the former. This conclusion follows from our earlier discussion about the distinction between unconditional and conditional refusals to license.

\section{Restrictions on the use of the intellectual property}

One of the very attractive features of intellectual property is that it can be divided up in various ways and thus efficiently combined with complementary assets. Let me illustrate this with one of the great process innovations of the past half-century: the "float glass" process developed by Pilkington in the 1950s and 1960s which revolutionised the production of flat glass around the world. (The process involves floating the glass on top of molten tin; it greatly reduced the cost and improved the quality of flat glass.) Pilkington chose to exploit its technology, which received various patents but also enjoyed protection in the form of trade secrets, using different business arrangements in different parts of the world. Pilkington, recognising that it lacked the capital and market presence to fully exploit the float glass process all around the world, relied on numerous licensees and joint venture partners to accelerate the use/diffusion of its new technology. A typical licensee might have the right to practice the Pilkington process only in certain countries; a typical joint venture might be confined to a given physical facility or location.

Such geographic restrictions are clearly pro-competitive: the ability to employ such restrictions increases the return to $R \& D$ investments and improves the efficiency with which the fruits of that $R \& D$ are diffused. In this respect, economists do not distinguish geographic restrictions from field-of-use restrictions that permit patent holders to exploit their discoveries using a mixture of business arrangements in different areas. Just as a patent holder may choose to exploit its invention on its own in one product market and by licensing in another market, a patent holder may choose to enter into a joint venture in one country or region and to vertically integrate and use its invention internally in another region. After a license or joint venture that contains geographic restrictions is initiated, competition policy should be highly sceptical of 
the later pleadings of a licensee to lift the geographic restriction. To illustrate, suppose that Pilkington had reserved the use of its float glass process in the United Kingdom to itself, but licensed PPG to use its process in the United States. Suppose that PPG later asserts that these restrictions protect Pilkington's dominant position in the flat glass market in the United Kingdom. If competition policy were to invalidate the geographic restriction, the end result would be to reduce the return to innovation and discourage innovators like Pilkington from offering licenses at all. The key here is that the hypothetical Pilkington license in no way restricted PPG from competing in ways that it was capable of in the absence of the license. So long as this condition is met, intellectual property can be exploited using different approaches in different national markets without diminishing competition in any of those markets. ${ }^{25}$

This same reasoning also applies to field-of-use restrictions. From an economic perspective, there is no fundamental difference between field-of-use restrictions and geographic restrictions. Both are ways that the innovator can offer partial rights to licensees, presumably rights tailored to the licensee's strengths. Economists widely recognise that such matching of complementary assets is highly efficient.

In the United States, these principles are reflected in the IP Guidelines, and are generally followed by the Courts: a patent holder is under no obligation to create or enable competition in the use of its patented technology. Great flexibility is available to patent holders to define the contours of the grant they offer to licensees. There is no particular reason why such grants must follow the contours of relevant product or geographic markets, for example. In the European Union, similar reasoning is reflected in the Technology Transfer Regulation, which extends a block exemption to certain licensing restrictions. ${ }^{26}$

Despite the Technology Transfer Regulation, holders of intellectual property rights seem to have somewhat less discretion under European law, in part because of the strong preference given in Europe to promote free trade among member countries. ${ }^{27}$ The EU and other jurisdictions should clearly recognise the large potential costs associated with legal rules limiting patent holders' rights to exploit their innovations efficiently: reduced return to innovation, incentive to refrain from licensing at all, and incentive to engage in vertical integration even when licensing would be more efficient. All of this can be expected to lead to slower rates of innovation and more sluggish diffusion of innovations that are made.

These same principles apply to geographic restrictions in agreements between, e.g. a manufacturer holding a patent and its distributors. Once one accepts the principle that innovation and diffusion are promoted by giving the patent holder the right to choose how to exploit its invention in different markets (geographic and field-of-use), this freedom should not be limited based on the vertical distribution system (vertically integrated ownership of distribution assets vs. reliance on independent distributors) adopted by the patent holder. To do so would distort the patent holder's choice of vertical relations with distributors. Again, the key distinction is between competition using the patented invention and competition with other, independent alternatives to the invention: while even a patent holder with monopoly power should have broad discretion in choosing how to assign geographic rights to distributors, it should not be permitted to enter into exclusive relationships with distributors that serve to exclude non-infringing rivals from obtaining effective distribution.

See http://europa.eu.int/eur-lex/en/lif/dat/1996/en_396R0240.html.

The author's understanding is that in both the US and the EU under the patent exhaustion doctrine, patent holders have limited ability to impose geographic restrictions on the resale of products that practice their patents. The discussion here is confined to restrictions imposed directly on the geographic scope of operations of the licensee to the patent. 


\section{Restrictions outside the scope of the intellectual property}

These same results do not apply to restrictions on licensees extending beyond the scope of the intellectual property being licensed. As noted above, potentially anti-competitive licensing restrictions are not confined merely to tying.

As a general rule, restrictions on the ability of the licensee to make products or use processes outside the patent grant can stifle competition. For example, if Pilkington had required its licensees to cease production of flat glass, even flat glass not produced using Pilkington's patented process, outside their licensed areas, such a restriction might well have been anti-competitive. ${ }^{28}$ The general principle is that restrictions should not prevent competition that would have occurred in the absence of the license, and that any restrictions crossing this line should have a sufficient business rationale to make up for any danger of anti-competitive harm. Restrictions that extend beyond the term or scope of the patent, exclusive dealing provisions, and tying requirements all tend to fall into the potentially harmful category.

28 In certain cases, such restrictions are justifiable as part of protecting legitimate intellectual property rights. For example, Pilkington might have argued that it was hard for Pilkington to determine whether certain glass was indeed made using Pilkington's patents and trade secrets, and thus that a broader ban is a reasonable part of a patent and trade secret license. Such justifications need to be evaluated on a case-bycase basis. 
DSTI/DOC(2002)11

\section{MERGERS AND ACQUISITIONS IN HIGH-TECH INDUSTRIES}

In high-tech industries, which can be defined for present purposes to be industries in which technology is rapidly changing, the competitive process itself especially requires that various assets be recombined to reflect changing market conditions. Naturally, the co-ordination of various and disparate assets - from brand names to patents and trade secrets to manufacturing skills to design know-how implies a corresponding need for firms to engage in various collaborative activities. Several forms of collaboration are discussed below, but the discussion starts with one particular form of collaboration: mergers and acquisitions, which bring various assets under common ownership and control. Due to space limitations, the treatment of mergers and acquisitions offered here is abbreviated; the aim is not to provide a comprehensive analysis of merger enforcement policy, a large topic indeed, but rather to establish a comparison point for the more extended discussion of collaboration among independent entities discussed below.

As a general matter, merger enforcement in high-tech industries follows the same principles that apply for mergers in other industries. At least for mergers between rivals, these principles are well articulated in the United States in the DOJ/FTC Horizontal Merger Guidelines. Nevertheless, merger enforcement in high-tech industries does tend to emphasise certain aspects of the analysis that may be less important in less dynamic industries. The comments below address these special features of high-tech merger enforcement.

First, concerns about innovation, rather than simply prices and output, are naturally more important in industries where the lion's share of consumer benefits derives from innovation and the resulting product improvements. While this is certainly true in such classic high-tech industries as computer software, microprocessors, and networking equipment, innovation is hardly an afterthought in many more mature or traditional industries such as chemicals, pharmaceuticals, military weapons systems, or medical equipment. Looking generally at the role of innovation competition in merger review, Gilbert and Tom report that, in the United States at least, many more merger challenges have been based on concerns about innovation during the 1995-1999 period than in the 1990-1994 time period. ${ }^{29}$ During 19901994, only three out of 135 merger challenges (3\%) alleged effects on innovation, in contrast to 49 out of 269 merger challenges (18\%) during the 1995-1999 time period. ${ }^{30}$ The overall increase in the number of merger challenges does not reflect a tightening of merger enforcement, but rather a sharp increase in the number of mergers and the value of merger activity. As shown in DOJ and FTC statistics, the percentage of Hart-Scott-Rodino filings that have led to more complete investigations (second requests) or to challenges has changed little, if at all.

Second, high-tech industries accentuate the usual problems associated with predicting future market conditions (either with or without a proposed merger). Historical market shares are likely to be less

29

Richard J. Gilbert and Willard K. Tom (2001), "Is Innovation King at the Antitrust Agencies? The Intellectual Property Guidelines Five Years Later,” Antitrust Law Journal, vol. 69, no. 1.

See Tables 1 and 2 from Gilbert and Tom (2001). The FTC especially gave an emphasis to innovation effects in their allegations about mergers, citing innovation concerns in 36 of 148 mergers (24\%) during the later period. 
meaningful in rapidly changing markets than in more stable markets. For example, in the proposed merger between Worldcom MCI and Sprint that was blocked, the market identified for Internet backbone services was changing rapidly, and there was no established methodology for measuring market shares in this complex network context, calling the significance of market shares into question. More generally, merger review may require predicting the significance of new technologies and products that have had relatively little by way of market testing so far. This is especially hard if legal rules are posed in terms of static market definition: as market conditions change, so can the delineation of relevant markets for antitrust purposes. These concerns can arise in a number of different ways. One frequent pattern occurs when a company with an established position based on older technology seeks to combine with another company with newer technology. Does the market share of the established company overstate its future competitive significance? Is the newer technology really the direction in which the market is going? Perhaps customers will only slowly adopt the acquired firm's technology, or even pick an alternative new technology. Another fact pattern involves two firms that have tried with limited success to compete using new technology (e.g. two e-commerce firms now under pressure) and seek to join forces. In all of these cases, predictions regarding the adoption of new technology are central to the merger analysis, which must be realistically forward looking.

Third, there may be considerable uncertainty about the scope and validity of intellectual property rights that are critical for market structure and competition. The problem of fashioning competition policy in the presence of uncertain intellectual property rights is discussed more generally below in the subsection on patent settlements. Here it is simply noted that a firm's ability to compete in the future, or to exclude other firms for that matter, may depend critically on the outcome of patent litigation, which competition authorities may have difficulty assessing. Also, if patents or copyrights form significant entry barriers, remedies can quite naturally involve various licenses that enable entry. Indeed, a look at the consent decrees settling merger cases in the United States shows that licensing remedies are quite common. ${ }^{31}$ Here one of the special features of intellectual property (no rivalry in use) comes directly into play: a rival can be made a more effective competitor with a license even while the merged entity retains the right to practice the same patent or use the same copyrighted material. This leads into another fascinating set of issues that arise when imposing licensing remedies in merger cases: what assets besides a patent or copyright license (such as know-how, manufacturing facilities, or personnel) do rivals need to compete effectively and thus replace any competition lost due to the merger?

31 See Gilbert and Tom for a further discussion of many of these cases, including: Glaxo/Wellcome in medicines for the treatment of migraine headaches; Ciba-Geigy/Sandoz in gene therapy treatments (very much a case about innovation); Lockheed Martin/Northrop Grumman in military electronics systems and military aircraft (emphasizing innovation based on future capabilities). It should be emphasised that licensing as a remedy in a merger case is a far cry from mandatory licensing simply to open up markets: the former preserves competition consistent with existing intellectual property rights, whereas the latter directly impinges on existing IPRs. 
DSTI/DOC(2002)11

\section{COLLABORATION: GENERAL PRINCIPLES}

\section{Growing need for collaboration}

When technology is in flux, businesses must adapt to remain innovative and to deploy efficiently new and improved technologies. This process of adaptation is critical to the operation of a market economy, and ultimately is driven by competitive forces. During such times of change, the need to reallocate and recombine existing assets is especially important. For these fundamental reasons, we have been seeing a wave of mergers and acquisitions and a veritable explosion of all manner of business collaboration during the past five to ten years. ${ }^{32}$ On any given day, newspapers relate the day's round of joint ventures, alliances, and other business partnerships.

History proves that combining different ideas/components is critical to harnessing a new wave of technology. As Hal Varian describes ${ }^{33}$ technological revolutions such as the harnessing of electricity and the emergence of the automobile tend to go through a series of predictable stages: experimentation, capitalisation, management, hypercompetition, then consolidation. Several of these stages inevitably require collaboration, and thus tend to raise antitrust issues: experimentation (requiring firms to combine assets, people, and intellectual property from various unexpected places), management (which can include the formation of new entities tailored to take advantage of the new technology), and consolidation. As with other technology revolutions, the current collaborations, especially in the area of information technology, primarily involve vertical or complementary relationships, or involve firms that operate in quite different areas, rather than horizontal relationships between or among direct rivals.

The importance of working with customers, suppliers, and complementors finds support in prior OECD studies. ${ }^{34}$ Figure 1 of OECD report ${ }^{35}$, citing Science, Technology and Industry Outlook 2000, says that less than $20 \%$ of manufacturing firms consider competitors as a source of information that is "very important for innovation," vs. nearly $40 \%$ for customers and nearly $40 \%$ for others firms within the firm's group.

\footnotetext{
32 The growing importance of collaboration is also a function of changes in the corporation itself, including higher mobility of employees among jobs, greater decentralization of decision making in large organisations, and the increased use of outsourcing. Some of these changes are themselves driven by changes in information technology.

See Hal R. Varian (2000), “The Five Habits of Highly Effective Revolutions,” Forbes, February 21 available at http://www.forbes.com/asap/2000/0221/073.html.

OECD (2001), Innovative Clusters, Paris.

OECD (2001), Innovative Networks, Paris.

OECD (2000), Science, Technology and Industry Outlook 2000, Paris.
} 


\section{Most collaboration is not horizontal}

Before delving into the antitrust concerns associated with various forms of collaboration, it should be noted that the vast majority of collaborations proceed forward without objections on the part of competition authorities. In that spirit, what follows should be read as indicating just where the line is drawn, based on identifying the elements that might make a proposed collaboration anti-competitive. It appears that virtually all collaborations that businesses seek to undertake are able to go forward with little or no restrictions based on competition policy concerns. Why? For a great many collaborations, the participants are not direct rivals, or at most compete in limited areas and primarily complement each other. When Intel works with Duracell to improve batteries in laptop computers, competition problems are unlikely to arise. Furthermore, even when direct rivals seek to team up, the antitrust limits on their activities are pretty well understood, and they can proceed forward if they put in place proper safeguards to preserve competition amongst themselves.

\section{Classification of business relationships and antitrust concerns}

In turning to discuss various forms of collaboration, it is useful to classify firms according to their relationships with each other. The "Value-Net" of Brandenberger and Nalebuff provides a handy classification for our purposes. Taking the perspective of a single firm, other firms can be broken into four groups. ${ }^{36}$ First, there are competitors, who produce substitute products. Obviously, antitrust concerns are greatest when competitors team up, raising horizontal issues. Second, there are suppliers, who sell their goods or services to the firm in question. All manner of collaboration among customers and suppliers is of course very common. The issue with such vertical relationships is whether rivals at one level or the other are somehow excluded from the market. The third group is customers, who also are in a vertical relationship with the firm in question, just on the buying side rather than the selling side. Obviously, from a competition policy perspective the issues here are just the same ones that arise when buyers and sellers form relationships that go beyond simple spot-market transactions. The fourth group, and the least obvious, are firms that sell complementary products, i.e. products used in conjunction with the firm's products to build valuable systems. Brandenberger and Nalebuff call firms in this groups complementors to the original firm. The firms' relationship with its complementors is neither horizontal nor vertical (although it is far closer to vertical); we might think of it as diagonal.

To illustrate, consider Intel in its role as a supplier of microprocessors. Intel's competitors include AMD and Sun, both also selling microprocessors. Intel's customers include computer manufacturers such as Dell, Gateway, and Compaq. Intel's suppliers include Applied Materials (which sells semiconductor manufacturing equipment) and suppliers of raw materials. Intel's complementors are firms that supply other components to Intel's customers, including operating systems (Microsoft), application software loaded onto computers by OEMs (Adobe, AOL), chipsets (VIA) and graphics chips. As emphasised in Co-opetition, the relationship between two companies may well have multiple aspects: Apple and Microsoft are competitors (both sell operating systems), complementors (Microsoft software and Apple software may be used together by OEMs), and Microsoft is a supplier to Apple (with Office and Internet Explorer for the Macintosh computer). These mixed relationships are especially challenging both for businesses and for competition authorities, to the extent that the firms' business dealings in one area spill over and influence their dealings in other areas.

36 Adam Brandenberger and Barry Nalebuff, Co-opetition (1996), Doubleday, and Adam Brandenberger and Barry Nalebuff (1995), "The Right Game: Using Game Theory to Shape Strategy," Harvard Business Review, July/August. 
DSTI/DOC(2002)11

\section{Forms of collaboration}

An enormous variety of forms of collaboration are used routinely by businesses. The competition policy issues that arise for several such forms are discussed immediately below. Economists find it helpful to array the various forms along a spectrum ranging from full integration or ownership and control (mergers and acquisitions) to spot agreements between buyers and sellers to engage in specific transactions. Moving along the spectrum in that direction, we have: mergers and acquisitions; joint ventures (common ownership and control); alliances (looser agreements to co-operate that tend to cut across a number of business areas, implemented in each area through a specific agreement); long-term contracts (such as supply agreements), short-term contracts, and, finally, arms-length spot-market transactions.

\section{General concerns about competition}

From the perspective of competition policy, the key issues in looking at any relationship is how the relationship affects the incentives of the parties to act in the future and how it enables or constrains the abilities of the parties to act in the future.

To illustrate, consider the announcement that Sony and AOL Time Warner had formed a partnership to provide AOL's popular e-mail, instant messaging, and chat functions on Sony's Playstation 2 video game machine. One could consider how this agreement might affect competition either among video game machines (where Sony competes against Nintendo and Microsoft's new Xbox system) or e-mail and instant messaging (where AOL is the clear leader in terms of users but again competes against Microsoft and others). If the agreement is non-exclusive, it primarily enables Sony to offer a more attractive system against Microsoft and Nintendo, and may also enhance the value of AOL's instant messaging system by increasing usage and thus positive network effects. This is common for nonexclusive, non-horizontal partnerships: they tend to create new products or enhance existing products, which is pro-competitive. What about the impact of the partnership on incentives? The partnership may enhance the incentives of Sony and AOL to promote their products together, which is pro-competitive; the partnership may reduce the incentive of either party to form another partnership, but this is a common result of forming a partnership and would not, of itself, indicate that the partnership was anti-competitive. This type of analysis reveals quickly why market structure (number of suppliers, market shares, entry conditions) for each product is important.

As a general rule, shorter-term contracts, and spot relationships are, ceteris paribus, less worrisome from a competition policy perspective than are mergers, joint ventures, or long-term contracts. But even short-term arrangements can raise concerns if they have an element of exclusivity. Exclusive dealing provisions are most likely to exclude competitors when employed by a dominant firm using a "divide and conquer" strategy against an uncoordinated set of customers, each of whom may be willing to agree to exclusivity in exchange for modest financial incentives. If such exclusivity provisions are widely used by the dominant firm in its relationships with key suppliers, customers, or complementors, survival may become much harder for the dominant firm's current competitors, and entry much harder for new would-be rivals to the dominant firm. Such exclusivity can arise in the context of the intellectual property licenses used by the dominant firm, or it can occur quite apart from intellectual property. 


\section{COMPETITION POLICY AND COLLABORATION}

Competition authorities have not neglected to notice the increasing role of collaboration in the information economy. In the United States, the FTC and the DOJ issued their "Antitrust Guidelines for Collaboration Among Competitors" ${ }^{\$ 37}$ in 2000. The same year, the European Commission issued regulations regarding specialisation agreement $\mathrm{s}^{38}$ and regarding research and development agreements. ${ }^{39}$ In 2001, the European Commission issued its complementary "Guidelines on the Applicability of Article 81 of the EC Treaty to Horizontal Co-operation Agreements", Official Journal C3, 06/01/2001, p. 02-30 available at http://europa.eu.int/comm/competition/antitrust/legislation/. These are extensive documents that cover many of the antitrust issues arising from various forms of collaboration; there is no attempt to summarise them here. However, it appears that officials on both sides of the Atlantic, faced with a sharp increase in the number of collaborative arrangements brought to their attention, found it helpful to provide further clarification to the business community on how these business plans would be viewed.

\section{Joint ventures}

The category of joint ventures covers a wide range of collaboration, ranging from nearly full mergers to quite limited and even temporary partnerships. Usually, economists reserve the term "joint venture" for collaborations that create a separate entity, jointly owned by the parents, that has some operational independence. The governance of joint ventures, the distribution of profits from joint ventures, the scope and lifetime of joint ventures, inter alia, varies a great deal from one venture to another.

Antitrust concerns tend to be minimal regarding joint ventures unless the parents are direct competitors. In that case, the venture may replace independent competition by the parents, or may serve as an information conduit to reduce competition between the parents. Ancillary restraints can also raise genuine antitrust questions: the parents may agree to work exclusively through the venture in a certain field: this can help overcome free-rider problems and generally motivate them to commit more resources and effort to the success of the venture, but it can also reduce competition in the markets in which the venture operates. Case-by-case analysis of such restraints is needed, looking at actual competitive effects.

The Annual Report on Competition Policy Development in the European Commission for 1999 discusses the treatment of "full-function" joint ventures. ${ }^{40}$ The Commission notes that a joint venture might enable co-ordination between the parents. This doctrine was applied in the BT/AT\&T case, a phase II merger proceeding. AT\&T agreed to divest ACC, a wholly-owned subsidiary of AT\&T, BT, and Telewest. Another good example of a joint venture studied by the European Commission was British Interactive Broadcasting (BiB), now known as "Open." Open was to provide digital interactive television services in the United Kingdom. Classic potential competition issues arose regarding the parents, BT and BSkyB: the

\footnotetext{
$37 \quad$ See http://www.ftc.gov/os/2000/04/ftcdojguidelines.pdf.

38 See http://europa.eu.int/eur-lex/en/lif/dat/2000/en_300R2658.html.

39 See http://europa.eu.int/eur-lex/en/lif/dat/2000/en_300R2659.html.

40 See http://europa.eu.int/comm/competition/annual_reports/1999.
} 
Commission was concerned that both parents might have entered this market on their own had they not joined $\mathrm{BiB}$. Undertakings to reduce barriers to entry were acceptable to the Commission.

The European Commission continues to gain experience with a variety of joint ventures, including the Shell/BASF joint venture in polypropylene and polyethylene, the Engine Alliance between Pratt \& Whitney and General Electric in jet engines, and the KLM/Alitalia joint ventures in airlines. An extensive discussion of how various joint ventures have been treated in the EU is available in the European Commission note to the OECD Roundtable on "Competition Issue in Joint Ventures".

\section{Standard setting}

Standard setting is an increasingly important form of co-operation or collaboration in the information economy. Virtually every major firm in the information and communications sector either participates in standard setting or at least must comply with standards promulgated by others. There are hundreds of official standard setting bodies throughout the world, including the International Telecommunications Union (ITU), the Institute of Electric and Electronic Engineers (IEEE), the American National Standards Institute (ANSI), the National Institute of Standards and Technology (NIST), and the European Telecommunications Standards Institute (ETSI), to name just a few. There are also a great many so-called Special Interest Groups (SIGs) that offer forums for the exchange of information about product specifications.

To be meaningful, standards must be adopted widely, if not universally. What good would a modem standard be if only one-quarter of the modems complied with it? (Indeed, the 56k-modem standards war delayed the adoption of these modems until a single standard was adopted.) Therefore, inevitably, standard setting sweeps in direct competitors, such as rival modem manufacturers. Worse yet, at least from a superficial antitrust perspective, standard setting typically involves an "agreement" among rivals, and thus is vulnerable to being characterised as some form of collusion. Such a view is not entirely erroneous, especially if rival firms agree only to make products that comply with a standard: this is in fact agreeing to "limit competition" in certain ways, i.e. by agreeing not to produce incompatible products. Obviously, standards typically benefit consumers by ensuring compatibility, but this fact does not imply that companies participating in standard-setting activities can use standard-setting as a smokescreen for engaging in price fixing or can otherwise ignore rules prohibiting collusion.

Standards fundamentally alter the nature of competition. If standards are put into place and widely adopted, competition occurs "within the market" among products adhering to those standards. Competition "within the market" is ongoing, driven by traditional factors such as manufacturing skills, ability to cut costs, marketing and distribution. Without standards, especially in markets with strong network effects that are likely to "tip" to a single technology or format, competition takes a very different form: competition "for the market" in which each firm (or coalition) attempts to gain dominance in a standards war. Competition "for the market" tends to be intense during the standards war but may be less once the war is over, at least if a single firm comes to dominate and control the winning technology and lacks significant ongoing pressure from other technologies.

Two big issues arise in establishing competition policy in the area of standard setting. First, what are the limits on the co-operative activity permitted as part of the standard-setting process? Second, what

41 DAFFE/CLP(2000)33 (PP.127.140). See http://www.oecd.org/daf/clp/roundtables/jvent.pdf. 
are the limits on unilateral conduct that might allow a single firm to control a standard that would otherwise be "open"? These are addressed in turn. ${ }^{42}$

\section{Co-operation or collusion?}

The pro-competitive benefits of standards are widely recognised. There are hundreds of thousands of standards, and no group of companies has ever been held to have violated antitrust law simply by virtue of agreeing on a standard. In the United States, the legal cases testing the limits of standardsetting have tended to be in the area of safety or performance standards rather than compatibility standards. These cases indicate a concern that the standard-setting process not be manipulated or structured to favour one firm or a group of firms over others. ${ }^{43}$

Beyond these concerns about process, many if not all standard-setting organisations have responded to antitrust concerns by limiting the topics that participating firms are permitted to discuss under the auspices of the organisation. In particular, many commercial issues are regarded as off limits, especially pricing of the products that comply with the standard. This limitation is both prudent and appropriate: it is hard to think of a reason why agreeing on a technical standard, which regards product characteristics, requires a discussion of the pricing of the resulting products.

Unfortunately, many standard setting bodies are so skittish about any discussions of "price" that they have discouraged discussions of the terms on which patents will be licensed among participating firms. The discussion below illustrates how this has led to problems associated with vague promises on the part of patent holders to license their patents essential to compliance with the standard on "fair, reasonable, and non-discriminatory" terms.

Certain other restrictions can also be entirely reasonable in the context of a standard-setting effort, but require study on a case-by-case basis. The most notable and obvious restriction is an agreement by various participants that they will only produce products that comply with the standard. Here there is an inevitable trade-off: such restrictions could be used unreasonably to limit competition in terms of product characteristics, but the commitment to the standard embodied in such an "exclusivity" pledge might be critical for getting the standard to be widely adopted in the first place. Competition authorities should evaluate such restrictions on a case-by-case basis and not attempt to invoke some per se rule, e.g. by characterising such agreements as "group boycotts" or "concerted refusals to deal" and thus automatically prohibited.

\section{Keeping standards “open”}

Standards are excellent from a competition policy perspective when they assure compatibility (thus harnessing network effects) and enable competition (thus ensuring competitive prices and competition to introduce improvements that do not introduce incompatibilities). When a uniform specification becomes widely used, i.e. truly a "standard" rather than a mere "would-be standard," compliance with that specification can become critical for market acceptance. Thus, a single firm controlling the standard could well have significant market power, even a dominant position.

\footnotetext{
$42 \quad$ For a more complete discussion on this point, see Carl Shapiro, "Setting Compatibility Standards: Co-operation or Collusion?" in Expanding the Bounds of Intellectual Property, Rochelle Dreyfuss, Diane Zimmerman, and Harry First, eds., 2001, Oxford University Press.

See the paper noted above as well as James Anton \& Dennis Yao (1995), "Standard-Setting Consortia, Antitrust, and High-Technology Industries,"Antitrust Law Journal 247, vol. 64, pp 247-265.
} 
For precisely this reason, companies will have an incentive to try to "hijack" an open standard and control it, make it proprietary. This is a form of opportunism: other suppliers, complementors, and consumers might well adopt a standard on the promise or expectation that it would be open. Competition policy issues are directly implicated when a single firm acts to gain control of a standard that was previously open, or that was expected to be open based on prior representations.

All major standard-setting bodies have rules intended to prevent this type of "hijacking" of a standard. The usual rules require that participants in the standard-setting process agree to make all intellectual property essential to compliance with the standard available either royalty-free or in exchange for "fair, reasonable and non-discriminatory" (FRND) royalties, which have been called "friendly" royalties.

The primary guiding principle in this area is that firms reneging on prior explicit "openness" commitments should be held accountable under competition law, not just contract law. To implement this policy principle requires a close look at the facts in each case. Just what commitment to "openness" did the firm make? Was reliance on that commitment important in the adoption of the standard? And has the standard in fact been successful, so the firm can be seen as controlling a relevant market?

A leading US example in which a firm was found (at least by the FTC if not a Court) to have violated the antitrust laws based on its attempt to control a standard is the FTC case against Dell Computer, announced in November 1995. The FTC alleged that Dell threatened to exercise undisclosed patent rights against computer companies adopting the VL-bus standard, a mechanism to transfer data instructions between the computer's CPU and its peripherals such as the hard disk drive or the display screen. The VL-bus was used with 486 chips, but it has now been supplanted by the PCI bus. According to the FTC,

\begin{abstract}
"During the standard-setting process, VESA [Video Electronics Standard Association] asked its members to certify whether they had any patents, trademarks, or copyrights that conflicted with the proposed VL-bus standard; Dell certified that it had no such intellectual property rights. After VESA adopted the standard - based in part, on Dell's certification-Dell sought to enforce its patent against firms planning to follow the standard. ${ }^{, 44}$
\end{abstract}

The Dell case stands for the proposition that a company participating in a standard-setting process is subject to antitrust liability if it fails to abide by the rules associated with that process and thereby harms competition. Hopefully, the Dell case has sent a signal to companies that they cannot "hijack" a standard using intellectual property that they failed to disclose as required by the standardsetting organisation. ${ }^{45}$

Another good example is the case of Motorola and the V.34 modem standard adopted by the International Telecommunications Union. Motorola agreed to license its patents essential to the standard case to all comers on "fair, reasonable, and non-discriminatory terms." Once the standard was in place, Motorola then made offers that some industry participants did not regard as meeting this obligation. Litigation ensued between Rockwell and Motorola, in part over the question of whether "reasonable" terms should mean: $a$ ) the terms that Motorola could have obtained ex ante, in competition with other technology

\footnotetext{
$44 \quad$ See http://www.ftc.gov/opa/1996/9606/dell2.htm

45 Beyond this core principle, there were two controversial issues surrounding this consent decree: $a$ ) the FTC did not assert that Dell acquired market power, and indeed the VL-bus never was successful; and $b$ ) the FTC did not assert that Dell intentionally misled VESA. Anti-competitive harm is unlikely to arise in the absence of significant market power and the competitive effects are not dependent on Dell's intentions.
} 
that could have been placed in the standard; or $b$ ) the terms that Motorola could extract ex post, given that the standard was already set and Motorola's patents were essential to that standard.

These issues are best dealt with by the standard-setting bodies, or standard-setting participants, either by making more explicit the duties imposed on participants, or by encouraging ex ante competition among different holders of intellectual property rights to get their property into the standard. Unfortunately, antitrust concerns about "price fixing" have led at least some of these bodies to steer clear of such ex ante competition, on the grounds that their job is merely to set technical standards, not to get involved in "prices," including the terms on which intellectual property will be made available to other participants. The ironic result has been to embolden some companies to seek substantial royalties after participating in formal standard setting.

More recently, in a private action, Rambus was found by a jury to have acted improperly in its use of patents at the Joint Electron Device Engineering Council (JEDEC), the semiconductor engineering standardisation body of the Electronic Industries Alliance (EIA), a trade association for the electronics industry. ${ }^{46}$ JEDEC rules required that participants agree to disclose any patents that might cover the relevant technology to the other JEDEC participants. The jury found that Rambus had committed fraud by not disclosing its patent applications to JEDEC, which was in the process of setting standards for DRAM, a form of computer memory. The plaintiff in the case, Infineon, alleged that Rambus failed to disclose applications for more than 30 patents that might cover the technology incorporated in the standard. Infineon also alleged that Rambus used its knowledge of JEDEC's plans to rewrite patent applications so they could cover the technology being contemplated as a standard. Rambus asserts that it followed all of JEDEC's disclosure rules. This case should serve as a reminder to standard-setting organisations to be extremely explicit about their disclosure (and licensing) rules, and to participants that they must fully comply with such rules. Certainly, a vague obligation to license essential patents on FRND terms is insufficient: participants should insist that patent holders either agree to royalty-free licenses or specify in advance the precise terms on which licenses will be offered.

A potentially deeper problem arises if firms choose not to participate in the standard-setting effort, perhaps intentionally in order not to be bound by the relevant disclosure and licensing rules. This appears to be an unavoidable risk facing companies participating in standard-setting: that they will pick a technology that will become embodied in a successful standard, only to find that a firm that did not even participate in the standard-setting effort is asserting its patents against products complying with the standard. There is little that competition policy can do to avoid this danger, although recent changes in the United States to require disclosure of some patent applications can help reduce the extent of the "hold-up" problem. ${ }^{47}$

Another potential danger area arises if the obligation of participants to license patents only extends to "essential" patents, i.e. patents necessary to implement the standard. This can create a strange situation in which a patent holder argues that its patent is merely a "useful feature," not a truly "essential" patent. If the useful feature becomes commercially necessary, if not technically required by the patent, a single firm may effectively control the standard. Again, there is a risk of imposing overly sweeping or

$46 \quad$ The case was reported in the Wall Street Journal, "Rambus is Ordered by Jury to Pay USD 3.5 Million to Infineon Over Patents," May 10, 2001. Information about JEDEC can be found at http://www.jedec.org/Home/about_jedec.htm.

47. The American Inventors Protection Act of 1999 requires publication of most patent applications filed on or after November 29, 2000. After that date, an applicant may request that an application not be published only if the invention has not been, and will not be, the subject of a patent application filed in a foreign country that requires publication of patent applications 18 months after filing (or earlier claimed priority date) or under the Patent Cooperation Treaty. 
unclear requirements on participants: requiring that a broader range of patents be licensed can either discourage $R \& D$ (which might otherwise give individual firms a competitive advantage) or participation in the standard-setting process itself. Again, the best way to handle these problems is to be as explicit as possible at the outset as to just which technologies or patents will be considered "essential" vs. "optional" or "features."

At least in the United States, where private antitrust actions are common, there will inevitably be some plaintiffs who attempt to pursue their own private interests, even when the public interest in competition is not served. As long as the Courts follow sound economic principles in deciding these cases, standard-setting efforts should not be impeded. One example of such a case is the action brought by MultiVideo Labs (MVL) against Intel, alleging that Intel was acting improperly with regard to the standard for the Universal Serial Bus (USB). ${ }^{48}$ There was no dispute that the USB was an innovation highly beneficial to customers: it allows a great many peripheral devices to connect more simply to personal computers. Intel played a leading role in developing the USB standard. MVL sought to make products that did not comply with the USB specifications, and when the USB standard-setting body refused to certify these products as compliant, MVL sued, alleging that its products were being excluded from the market for anti-competitive reasons. In a strong opinion, the Court ruled against MVL, finding that enforcing the integrity of a standard is pro-competitive. The Court noted that there was nothing preventing MVL from making non-compliant products and claiming that they were superior (assuming this would not be a false or misleading claim); MVL was simply barred from using the USB logo and falsely claiming compliance. The lesson here is that a standard-setting entity, even a dominant firm or a group of competitors, can act to deny non-compliant products from using the brand name or logo associated with the standard.

\section{Cross-licenses}

Cross-licenses are mutual arrangements between or among rights holders by which each gains rights to make use of intellectual property owned by the other(s). For example, IBM and Motorola might enter into a cross-license to share their patents and/or trade secrets regarding certain technologies for the manufacture of semiconductors. There is no doubt that cross licenses can be a great boon to competition and innovation. The most attractive cross-licenses are those that give each firm considerable design freedom, i.e. the freedom to design and introduce new products without fear of infringing on the other firm's patents, and without imposing any running royalties. For example, Intel has cross-licenses of this general type with a number of other major firms in the semiconductor industry.

One cause for concern might be that a firm agreeing to license its future patents will have reduced incentive to conduct $R \& D$ and obtain such patents, knowing that the cross-licensee would be able to practice these patents. While this concern is perfectly correct as a matter of theory, in practice it appears that the freedom from being held-up (having to pay royalties on patents that have not yet been issued for products designed without knowledge of the relevant patent applications) is far greater, so broad crosslicenses stimulate both innovation and competition. ${ }^{49}$ In part this results from the fact that many patents appear to be issued covering technology that others are already practising, or independently deploying, before the patent is granted (and thus disclosed). As noted earlier, this suggests the need for reform of the patent system, a topic beyond the scope of this paper.

\footnotetext{
48 See MultiVideo Labs, Inc. vs. Intel Corporation, 98 Civ. 3908 (DLC), US District Court, Southern District of New York, 1998. The author served as an expert witness for Intel in this case.

This same point applies to various "grantback" provisions in licenses, i.e. provisions under which the licensee agrees to make certain future patents available to the licensor.
} 
Cross-licenses can, however, be abused. The most obvious danger arises when two direct competitors agree to charge running royalties to each other for various patents that they hold. The effect of such royalties will be to raise the price of the final product, since running royalties are a marginal cost. While such royalties might be perfectly reasonable, e.g. if each company holds a blocking patent, competitors have an incentive to use such royalties as a means of effectuating a cartel or monopoly outcome. One possible indication of such an anti-competitive plan is an agreement by the two firms to pay royalties even on products that do not infringe on the other's patents. Another red flag is the payment of fixed fees from firm A to firm B as part of a licensing agreement under which firm B then pays running royalties to firm A. This structure can raise firm B's marginal costs, and thus prices, with the fixed fee from A to B compensating B for its elevated costs. Cross-licenses can be anti-competitive if they reduce the ability of one or both firms to compete; one firm may agree to hinder its own ability to compete either $a$ ) in exchange for valuable consideration, or $b$ ) in exchange for a like agreement by a rival.

The use of cross-licenses can also interact with the "refusal to license" issues for dominant firms discussed earlier. The FTC's case against Intel was precisely such a case: the FTC alleged that Intel had monopoly power over microprocessors and was acting anti-competitively by refusing to license certain trade secrets to firms that would not enter into cross-licenses with Intel. ${ }^{50}$ As indicated earlier, since Intel was licensing its trade secrets only under certain conditions, this is not simply a matter of Intel exercising its rights not to license intellectual property. However, this issue primarily arose between Intel and its customers, and thus had no obvious impact on competition in the market that Intel was alleged to dominate. Indeed, Intel described its conduct as a pro-competitive policy of "IP for IP," which would primarily have the effect of making it more difficult for companies benefiting from Intel's patents and trade secrets from holding up Intel by asserting their patents against Intel. Ultimately, a settlement was reached between the FTC and Intel under which Intel would not withhold trade secrets from a customer in response to a patent suit initiated by that customer so long as that customer agreed not to seek an injunction against Intel for patent infringement.

\section{Patent pools $^{51}$}

A patent pool involves a single entity (either a new entity or one of the original patent holders) that licenses the patents of two or more companies to third parties as a package. Patent pools, while less common than cross licenses, are another natural way in which companies can combine their patents and thus promote diffusion, even while enhancing the returns to innovation. Generally speaking, patent pools are highly pro-competitive so long as they combine complementary patents and not substitute patents. ${ }^{52}$

The US Department of Justice has clearly articulated its policy towards patent pools/package licensing in a trio of business review letters regarding an MPEG patent pool and two DVD patent pools. The essence of this approach, which has strong support in economic theory, is that inclusion of truly complementary patents in a patent pool is desirable and pro-competitive, but assembly of substitute or rival patents in a pool can eliminate competition and lead to elevated license fees. Put differently, the key

50

See http://www.ftc.gov/os/1999/9908/intel.do.htm. The author served as an expert witness for Intel in this case.

Material in this section is taken in part from Carl Shapiro, "Navigating the Patent Thicket: Cross Licenses, Patent Pools, and Standard-Setting," in Innovation Policy and the Economy, Adam Jaffe, Joshua Lerner, and Scott Stern, eds., National Bureau of Economic Research, 2001.

For a discussion of patent pools (as well as cross-licensing) reflecting the DOJ position on these issues, see Joel I. Klein, (1997), "Cross-Licensing and Antitrust Law," at http://www.usdoj.gov/atr/public/speeches/1123.htm. 
distinction in forming a patent pool is that between "blocking" or "essential" patents, which properly belong in the pool, and "substitute" or "rival" patents, which may need to remain separate.

In the MPEG case, ${ }^{53}$ the Department approved the creation of a pool of patents necessary to enable manufacturers to meet the MPEG-2 video compression technology. This pool, encompassing patents from Fujitsu, General Instrument, Lucent, Matsushita, Mitsubishi, Philips, Scientific-Atlanta, Sony, and Columbia University, permits "one-stop shopping" for makers of televisions, digital video disks and players, telecommunications equipment as well as cable, satellite, and broadcast television services. To support their formation of a patent pool, these nine patent holders conducted an extensive search to identify all patents essential to the MPEG-2 standard and include them in the pool. The licensing agent for the pool, MPEG LA, will employ an independent patent expert to determine whether a patent in the pool is in fact essential, and whether other patents are essential and thus suitable for inclusion in the pool. As stated by the Department, "the use of the independent-expert mechanism will help ensure that the portfolio will contain only patents that are truly essential to the MPEG-2 standard, weeding out patents that are competitive alternatives to each other."

In the first Digital Versatile Disk (DVD) $c a s e,{ }^{54}$ the Department approved a proposal by Philips, Sony, and Pioneer to jointly license patents necessary to make discs and players that comply with the DVD-Video and DVD-ROM standards. Again, only essential patents are to be included in the joint licensing program. As with the earlier CD licensing program of Sony and Philips, licenses will be offered by Philips, in this case on behalf of all three firms. Again, an independent patent expert will be employed to ensure that the license only conveys the rights to essential patents. As stated by the Department, "the expert will help ensure that the patent pool does not combine patents that would otherwise be competing with each other." The Department subsequently approved a second joint licensing scheme relating to the DVD-Video and DVD-ROM standards, ${ }^{55}$ this one including patents held by Toshiba (the licensing entity), Hitachi, Matsushita, Mitsubishi, Time Warner, and Victor Company of Japan. Note that the effect of these two patent pools appears to be to reduce but not eliminate the complements problem, since there remain two separate pools, not just one: "two-stop shopping," it would appear.

In contrast to the Department of Justice's approval of these three patent pools, the US Federal Trade Commission in March 1998 challenged a patent pool formed by Summit Technology, Inc. and VisX, Inc. two firms that manufacture and market lasers to perform a new, and increasingly popular, vision correcting eye surgery, photorefractive keratectomy. ${ }^{56}$ According to the FTC: "Instead of competing with each other, the firms placed their competing patents in a patent pool and share the proceeds each and every time a Summit or VISX laser is used." The FTC was ostensibly following the same principles employed by the Justice Department, namely to permit the assembly of complementary or essential patents, but not rival patents, into a pool. According to the FTC, the two companies agreed not to license their patents independently. However, the companies in this case argued vigorously that they did indeed have mutually blocking patents, making their pool, Pillar Point Partners, pro-competitive. In August 1998 the two companies settled with the FTC and agreed to lift any restrictions on each other regarding the licensing of their patents; ultimately, their patent pool was dissolved. ${ }^{57}$

\footnotetext{
53 See the June 26, 1997 press release, http://www.usdoj.gov/atr/public/press_releases/1997/1173.htm.

54 See the December 17, 1998 press release, http://www.usdoj.gov/atr/public/press_releases/1998/2120.htm.

55 See the June 10, 1999 business review letter, http://www.usdoj.gov/atr/public/press_releases/1999/2484.htm.

See the March 24, 1998 press release, http://www.ftc.gov/opa/1998/9803/eye.htm.
}

For a description of the settlement, see the August 21, 1998 press release, http://www.ftc.gov/opa/1998/9808/sumvisx.htm. Despite this settlement, the FTC continued to pursue Vis X for allegedly acquiring a key patent by inequitable conduct and fraud by omission on the U.S. Patent 
The Summit and VisX case raises a number of very interesting and tricky issues regarding patent pools and joint licensing programs. First, if Summit and VisX reasonably believed that their patents blocked each other at the time they formed the pool, was that sufficient to justify the formation of a pool? How hard were they required to look into the validity of each other's claims before agreeing to form Pillar Point Partners? Second, if each firm believed it could, at considerable expense, delay, and risk, invent around the other's patents, should the two firms be prohibited from forming a pool and rather forced to attempt to invent around each other's patents, under the view that the consumer might thereby enjoy the benefits of direct competition (although the product might be delayed, or never introduced, in the absence of the pool)? Third, is there competitive harm in placing some potentially rival patents into the pool, assuming that each party in fact controls valid blocking patents, making some type of pool procompetitive? Fourth, can the pool be attacked on antitrust grounds based on the argument that a less restrictive alternative, namely a royalty-free cross-license, would have achieved the same legitimate purposes and created additional competition? If so, does it matter in this assessment that Summit and VisX agreed that the pool would license their patents to third parties, something that a cross-license would not permit, unless it contained rather unusual sublicensing rights? These questions, or their analogs, will generally be important in cases involving patent pools.

\section{Patent settlements}

A final area of interest concerns the limits on patent settlements between rivals. While settlements are generally welcomed by the Courts, and while most licenses and cross-licenses can be regarded as forms of settling patent disputes, the possibility clearly exists for rivals to use the settlement process to restrict competition in ways not merely reflective of their valid intellectual property rights.

The leading US cases along these lines are the FTC's various actions against settlements between branded pharmaceutical manufacturers and generic challengers. ${ }^{58}$ The typical pattern in these cases looks like this: a pharmaceutical manufacturer with a patented, branded drug is facing potential entry by a generic supplier. Generic entry would lead to a significant reduction in prices, to the benefit of consumers. However, the patent holder asserts that the would-be generic entrant infringes its patent, and seeks to block entry. Patent litigation ensues. Then a settlement is reached in which certain consideration passes from the patent holder to the challenger and in which an entry date for the generic supplier is negotiated. The FTC has generally been willing to challenge such agreements if the patent holder makes a payment to the challenger, on the theory that such payments effectively delay generic entry and thus lessen competition. This concern about an incumbent patent holder paying off would-be entrants is not confined to express agreements between branded pharmaceutical companies and generic entrants: a number of mergers can also be regarded as settlements of patent disputes that eliminate actual or potential competitors who are facing patent challenges from incumbents.

One way to balance the legitimate intellectual property rights of the settling parties with the interests of consumers is to adopt a competition policy that compares consumer benefits under a proposed settlement with consumer benefits from ongoing litigation. ${ }^{59}$ Settlements that raise consumer benefits (formally, consumer surplus) are considered pro-competitive. This standard explicitly recognises that some

and Trademark Office. However, an administrative law judge subsequently dismissed this complaint; see the June 4, 1999 press release, http://www.ftc.gov/opa/1999/9906/visx.htm.

Gilbert and Tom (2001) contains an extensive discussion of these cases.

A much more complete discussion and more technical analysis of the antitrust limits to patent settlements is available in Carl Shapiro (2001), "Antitrust Limits to Patent Settlements;" see http://haas.berkeley.edu/ shapiro/settle.pdf. 
patents are weak in the sense that the probability they will be held valid and infringed is low, and that holders of weak patents cannot expect to reach settlements that restrict competition as much as can holders of strong patents. The patent right is probabilistic, not absolute. Put differently, a patent gives its holder the right to try to exclude, not the absolute right to exclude. 


\section{CONCLUSIONS AND RECOMMENDATIONS}

This paper has provided a framework for guiding competition policy in the areas of innovation and intellectual property. Based on underlying economic principles and selected cases, it suggests specific policy approaches to a variety of key policy issues that arise: mandatory licensing, the treatment of crosslicenses and patent pools, and the limits on settlement of patent disputes between rivals. There is no systematic evidence that competition policy has impeded innovation. To the contrary, with the exception of cases that treat the mere refusal to license as an anti-competitive act, the cases studied on the whole show a respect for intellectual property rights even while delineating the limits of such rights. Hopefully, the various OECD countries can learn from this study, and from the practices of the other countries, in the realms of competition and innovation policy. 